\title{
NATO Response Force and the EU Rapid Reaction Force: main challenges and opportunities
}

\begin{abstract}
A need for multi-dimensional effective institutional structure possessing various security instruments, have become obvious already by the end of the Cold war and is manifested itself even stronger at the beginning of the XXI century. Moreover globalization of the security concept makes it clear that security cannot be complete if it is not tackled globally. Aiming to react to changing security environment international security institutions during the last decade are undergoing essential changes, related to their missions, tasks, structures and instruments. Demand for small special forces, which possess the most advanced technologies, modern air force and efficient intelligence capabilities emerged. That stipulated changes in armed forces and armory.

NATO and the EU in the beginning of the XXI century have committed themselves for a new mission - to guarantee security and stability in the World. The main purpose of this article is to overview major steps of NATO and the EU transformation aiming to respond to the contemporary security challenges, to present an analysis of possible evolution of their new instruments NATO Response Force (NRF) and European Rapio Reaction Force (ERRP), to elucidate possible roles and interdependency of NRF and ERRF in the contemporary security architecture, and, finally to contemplate on the possible effects of both forces on international security.
\end{abstract}

\section{Introduction}

The end of the Cold War has introduced the revaluation of the main concepts in international affairs. Relations among states and also between the states and non-state actors changed. The obvious need to restructure institutional arrangements for cooperation, which would put the emphasis on essentially different threats and functions, have manifested itself during the past decade. Moreover, the end of two blocks' antagonism has introduced new opportunities for countries to fight the new threats and global challenges in common.

The end of bipolar world order had also negative consequences. Problems related to technological advance and globalization during the Cold war were restricted by deterrence policy, but have been unleashed when bipolar world order ceased to exist. The problematique of security has expanded to completely new fields and the significance of non-military threats increased.

\footnotetext{
* Margarita Šešelgyte - Lecturer of the Political Science Department of the Lithuanian Military Academy, Ph.D. candidate of the Institute of International Relations and Political Science of the University of Vilnius. Address: Šilo 5a, LT-2055, Lithuania, tel. + 37052103 571, e-mail: margo_ses@yahoo.com
} 
Development of modern technologies, advances of communication means, decreasing significance of space and time have intensified the expansion of negative phenomena and increased the destructive power of new threats. International migration, international crime, globalization of environmental problems, speedy spread of economic crises, social disorders, ethnic conflicts and terrorism have become more sighnificant by the end of the last decade of the XX century. Transformation of international system was accompanied with changes also in the nature of military threats. Military threats often are more internal rather than international phenomena. Majority of the conflicts after the Cold war have been fought not between the states but between the state and the antagonistic groups or among those inside the state. Traditional instruments of security prevention and enforcement have ceased to be effective when dealing with new types of conflicts.

Search for new instruments is complicated because of the vague understanding of what is supposed to be a threat and how it should be defined. Traditional threats prevailing during the years of the Cold war were easy to define. Consequently it was not that difficult to decide on the most proper instruments to deal with them. The ambiguity of contemporary threats provokes hot discussions not only over the instruments of prevention and combat but also over the very definition of a threat or aggressor. Trying to define a particular threat or aggressor disputes of philosophical character often arise, therefore it becomes even more difficult to reach a consensus among states.

Changes in international system and security problematique prompted more intense interactions among the states and the states and non-state actors. The need to establish multi-dimensional effective institutional structure that possess various security instruments have become obvious. In long-term security policy preventive actions and civilian instruments gained a special importance. Though collective defense remains an important instrument to fight traditional threats, more and more often, especially when the rapid reaction is required, there is a tendency to rely on crisis management instruments, which encompass various measures from direct use of force to indirect restrictions in the framework of international organizations. The significance of civilian capabilities has increased even in the military domain. The demand for small special forces, possesing the most advanced technologies, modern air force and efficient intelligence capabilities emerged stipulating transformation of armed forces.

Trying to react to the changing security environment international security institutions are also undergoing essential changes, related to their missions and tasks, structures and instruments. Main missions of NATO during the Cold war were collective defense and deterrence. With the end of the Cold war NATO was forced to find a new raison d'etre. Thus a new peacekeeping mission has been introduced for NATO and respective reforms of military command structures and capabilities, with the emphasis on mobile and flexible armed forces possible to be used in the regional conflicts, have started. The EU has also decided to expand its functions introducing a military dimension inside its structures. In the last decade of XX century the EU took over the functions of the WEU and committed itself for creating European Rapid Reaction Force (ERRF), capable of carrying out humanitarian operations, rescue tasks, peacekeeping and crisis management. In 2003 ERRF were declared 
operable and recently have started independent missions in FYROM and the Democratic Republic of Congo.

$\mathrm{Al}$ though aiming to react to the changes in international environment major international organizations have started respective reforms, those changes were insufficient to provide necessary means to fight such challenges as proliferation of weapons of mass destruction and terrorism. Military campaign in Afghanistan has showed that neither ERRF nor NATO are relevant for the operations demanding rapidity and flexibility. It became clear that if NATO does not acquire new instruments, the majority of military operations in future would be carried out in the framework of ad hoc coalitions and would negatively influence the credibility of the Alliance. In 2002 the Defense Secretary of the USA therefore have proposed a NATO Response Force (NRF) project, which might be estimated as a mean intended to "revitalize" the Alliance and to provide it with the new raison d'être. NRF project in fact envisages the creation of mobile rapid reaction force in NATO structures creating yet another mission for NATO - to ensure the prevention of international crisis, including the fight with asymmetric threats.

Transformation of international security organizations, which started immediately after the Cold war, is still ongoing. Thought it last already more than ten years the real consequences of it remains uncertain and encourages scholars from all over the world to contemplate on the possible consequences of this transformation it might be presumed that. NATO and the EU in the beginning of XXI century have committed themselves for a new mission - to guarantee security and stability in the World. The main purpose of this article is to overview major steps of NATO and the EU transformation aiming to respond to the contemporary security challenges, to present an analysis of possible evolution of NRF and ERRF, to elucidate possible roles and interdependency of NRF and ERRF in the contemporary security architecture, and, finally to contemplate on the possible effects of both forces' development on international security.

The first part of the article is devoted to the analysis of the perspectives of $\mathrm{NRF}$, identification of major problems and examination of possible impact of NRF development on the effectiveness of NATO, firmness of transatlantic link and international security. The analysis of ERRF prospects and problems is conducted in the second part. The third part of the article aims to evaluate the prospects of NRF and ERRF joint actions, to indicate possible challenges and explore their effects on the international security. The final part of the article briefly outlines the prospects of Lithuania's possible contribution to NRF and ERRF. 


\section{NATO Response Force (NRF) - "revitalization" of the Alliance}

The main outcome of NATO summit in 1990 was the common understanding of member states that the Cold war is over and that Europe faces a new era. It was emphasized that the new Europe needed a new NATO. Discussions on the future of the Alliance started. Some of the discussants have been claiming that Alliance has lost its relevance and that the days of NATO are counted. It was argued that disappearance of the major motivating factor - threat posed by the communist block - had condemned the organization for a slow death. There also happened to be many to believe that the World is turning into an age of a liberal democracy and peace. The world famous Francis Fukuyama bestseller "The End of the History and the Last Man"1 presented a new picture of peaceful world and became an inspiration for international relations analysts all over the world. Idealistic scenarios however were challenged by horrifying events in Balkans and former territory of the Soviet Union.

New conflicts, on the other hand, provided the Alliance with the opportunities to prove that although the threat of Communism have disappeared the Alliance is still necessary. Alliance's raison d'être was even more strengthened by the aspirations of the former Warsaw pact states to join NATO and the success of the latter in the Gulf war. It seemed that the Alliance survived existential crisis and pessimism towards NATO's future calmed down.

Thus, during the last decade of the XX century NATO members have committed themselves to undertake a new mission - peacekeeping. Growing demand for crisis prevention and management type missions after the Cold war was emphasized in 1992 in Oslo. North Atlantic Council (NAC) announced its readiness to support conditionally peacekeeping activities ${ }^{2}$. The USA has initiated discussions on NATO reform aiming to transform NATO from essentially military organization into the one of more political nature, able to undertake peacekeeping functions. NATO armed forces were decided to be reformed accordingly ensuring necessary flexibility, mobility and capacity to act in new circumstances. NATO armed forces together with partners carried out peacekeeping missions in Bosnia \& Herzegovina, Kosovo, FYROM. Yet those missions were far from smooth. It turned out that NATO forces were not effective when undertaking new tasks. Media was arguing that Serbs and Roma population were leaving Kosovo because they did not trust NATO forces as being able to ensure their security. Problems of a similar nature were troubling NATO in Bosnia \& Herzegovina and Croatia.

Former US Defense Secretary William Cohen when speaking about the NATO's readiness to take over new tasks admitted that peacekeeping missions require different preparation and different forces from those undertaking traditional tasks. He was confident that military force is not alvays the best solution in those cases ${ }^{3}$.

\footnotetext{
${ }^{1}$ Fukuyama F. The end of history and the last man, New York, Macmillan, 1989.

${ }^{2}$ Ministerial Meeting of the North Atlantic Council Final Communique, Oslo, 4 June, 1992, http:/ /www.nato.int/docu/comm/htm

3 “Peacekeeping Not NATO's Job says Cohen” Press Advisory: Basic Publications, 16 July 1999, http://www.basicint.org/pr_natopk.html .
} 
Moreover to participate in the operations overcoming the borders of the Alliance NATO had to have the adequate mandate issued by the UN. The procedure of the legalization of military operations usually takes a long time in the UN and often slows down the operation. On the other hand, UN mandate often limits activities of armed forces to the very marginal functions thereby reducing the expected efficiency of the operations and in some cases even endangering lives of soldiers. And still, although NATO was frequently criticized for its failures in solving regional conflicts, it is worth admitting that it was the one and only organization at that time able and having capacity to send military forces to the troubled regions.

Reforms to increase defense capabilities of the Alliance were started and included transformation of NATO military instruments and command structures. NATO states decided to develop mobile and flexible small armed forces able to operate in regional conflicts. Special peacekeeping units were to be introduced in the framework of ESDI enabling lightly armed European forces to take over the functions of civilian administration, police, conflict resolution, organization and supervision of the elections and the media monitoring. ${ }^{4}$ Aiming to improve NATO capabilities adapting them for crisis management Defense Capability Initiative (DCI) was introduced in Washington summit. Other reforms related to the mobility, logistics, sustainability, C2 systems were also introduced.

The fact that NATO was able to survive an existential crisis which emerged after the cold war and find the new role in the contemporary world prompted discussions on new era of the Alliance. However today optimism is being challenged again bringing the issue of NATO survivability back to the agenda of International Relations. Although the unity of NATO members after the terrorist attacks of September 11 in the USA gave an impression that the Alliance remains harmonious, effective and necessary, military campaign in Afghanistan have proved contrary - NATO was not suitable for the operations that require operability and flexibility - moreover it demonstrated the unwillingness on the US side to rely on the NATO structures when dealing with new type conflicts.

Article argues that although there are many factors causing the hardships NATO faces today, the prevailing and the most serious one is status of transatlantic link which for so many years used to be the cornerstone of NATO's existence and is challenging smooth functioning of the organization today. Weakening transatlantic link is, on one hand, related to the changes in the USA strategic thinking after the Cold war, on the other hand, is triggered by the growth of European economic and political power accompanied with its backwardness in military domain. Another important factor that might have an impact on transatlantic link is NATO's inability to fight the main threats of XXI century - proliferation of the weapons of mass destruction and terrorism.

\footnotetext{
4 "ESDI: Right Debate, Wrong Conclusions" Press Advisory: Basic Publication 8 September 2000, http://www.basicint.org.ciuunits.htm .
} 
Europeans are concerned about decreasing importance of NATO and accuse Americans for unilaterarism in international affairs thereby linking most of NATO problems to the unwillingness of the USA to rely on multilateral institutions. Americans, in their turn, tend to emphasize the "causes of this unwillingness": imperfect structure of the Alliance, too complicated and slow decision making procedure, UN restrictions, military backwardness of European allies. Although it seems that in general neither Europeans, nor Americans are interested in the dissolution of the Alliance, NATO the way it is, does not satisfy expectations of either side. Today NATO is undertaking the functions rather of a political forum than the ones of military alliance. It is true that even as a political forum the North Atlantic Alliance is beneficial for international security as it enhances cooperation and promotes democratic values. But are those functions sufficient for the Alliance to survive, moreover is this a role that members of the organization have envisaged for the Alliance in XXI century?

It is obvious that if NATO does not acquire new instruments enabling it to respond to the new challenges, majority of military operations will be carried out in the framework of ad hoc alliances or ad hoc coalitions. Although ad hoc alliances may produce short-term benefits, due to their temporal character and concentration on the clear threat as the main motivating basis for cooperation, they do not ensure the complete variety of measures necessary for the implementation of various functions of security policy. Moreover ad hoc structures might be successful only as long as the interests of participating parties coincide. One of the major shortcomings of ad hoc alliances is a lack of legitimacy, which has clearly manifested itself in Iraq.

Permanent security institutions, on the other hand, not only aggregate joint resources and provide basic structures to fight common threats, but have also disciplinary effect, that helps to solve "uncertainty problem". Through common rules permanent institutions are shaping models of behavior eventually strengthening common identity, enhancing closer cooperation, multilateral behavior. Consequently those institutions themselves become important actors in the security environment. Permanent structures of cooperation therefore are more appropriate organizations to carry out complicated tasks of contemporary security policy. And perhaps realizing this, members of the Alliance decided to NATO one more chance to prove its relevance.

Lord Robertson in his speech in Charles University in 2002 stated that entering the XXI century security organizations have to ensure prevention and management of international crises, including the fight with asymmetric threats..$^{5}$ As terrorism and proliferation of weapons of mass destruction have become principal threats for the security in the beginning of the XXI century, it was realized that NATO has to have means to fight them. However the main question - whether NATO willing and able to respond to this challenge remains open?

\footnotetext{
${ }^{5}$ Robertson G., NATO in the 21st Century. Speech by NATO Secretary General Lord Robertson at Charles University in Prague, Prague, March 21, 2002, http://www.nato.int/docu/speech/2002/ s020321a.htm.
} 
6 October 2002 Declaration of NATO Parliamentary Assembly admitted that NATO must consolidate defense against the threats of terrorism and proliferation of weapons of mass destruction, with the special attention to the fight against biological, chemical and radiological weapons. ${ }^{6}$ On 24 September the same year in Warsaw during its welcoming speech at the informal meeting of defense ministers the USA Defense Secretary Donald Rumsfeld warned that as long as NATO does not acquire mobile and rapid force, that is possible to deploy in few days or weeks, rather than months and years, this organization will not have anything to offer in the XXI century. ${ }^{7}$ To support his rhetoric with practical initiatives Rumsfeld at the same meeting introduced a project of NATO Responce Force (NRF) that proposed creation in NATO structures of mobile rapid reaction forces (20 $000 \mathrm{men}$ ), possessing all elements of land, sea, air forces and command able to deploy in 7-30 days. According to the project this force is not to be geographically limited and is designed to carry out operations outside NATO territory. NRF is planned to consist of the armed forces of NATO members ensuring high level of readiness, however it will not be kept on stand-by permanently, but rather separate units will be undergoing three rotational stages: training, mission or stand-by. While the force is on stand-by stage they will be under national military command, in the case of crisis - under the SACEUR. NRF is intended to carry out three types of operations: 1) force demonstration; 2) autonomous/ self-sufficient wide spectrum operations; 3 ) forward deployment operations to ensure deployment of regular forces. The project also planned to create a new chemical, biological, radiological and nuclear battalion in the framework of NRF.

Further steps in NRF development were taken in Prague summit. Although principal theme of the summit was supposed to be the enlargement it took somehow rather practical than sound character, with the main part of the event concentrating on the search for NATO's new mission in the XXI century and for the best structures to carry out new responsibilities. Aiming to make command structures more flexible respective reforms of were introduced, creating two strategic headquarters: in Europe and in the USA. New Prague Capabilities Commitment (PCC), which although criticized as simply being the new name to the failed project, was related to NRF and called the allies to strengthen special capabilities.

Reactions towards a newly introduced project were quite controversial. Some NATO researchers claimed that NRF project was introduced in Prague as a supplementary issue aimed to diminish the significance of the enlargement and calm down Russia. Others saw NRF as the last chance for NATO to improve its military capabilities. Some of them were convinced that this project could reduce fears of the European allies related to the increasing isolationism of the USA and might become a new basis for transatlantic cooperation. Despite the uneven evaluations of NRF among the researchers at the political level allies were fairly sympathetic towards NRF. Still it is worth mentioning that despite its advantages NRF is not a panacea for all NATO

\footnotetext{
${ }^{6}$ Simpson F., Lindborg Ch., "The Results of the Prague Summit and Challenges Ahead" http:// www.basicint.org/update/041202_PF.htm.

${ }^{7}$ BBC News World Edition, http://news.bbc.co.uk/2/hi/europe/default.stm, 25092002.
} 
troubles. Moreover some Europeans fear that it might become just a way for the USA to consolidate its dominant position in the World.

Europeans are also afraid that after the launch of the first NRF mission NATO would be transformed into "aggressive" alliance, which is globally projecting its power. This transformation could not be in consistence with European "regional-civilian" identity. The very fact that NRF is designed to hit preventive strikes against "rogue" states and according to the American understanding is not to depend on the mandate of the UN Security Council contradicts with one of the major principles of international law - inviolability of national sovereignty -, which is cherished by European countries so much.

French Defence Minister Michelle Alliot-Marie worries that the erasure of geographical limits of the Alliance's operations might be dangerous as creating opportunities to start actions almost under all conditions. ${ }^{8}$ The Minister asks: "who will judge?" Trying to answer this question two concomitant questions arise. Can NRF become simply an instrument to defend the USA interests globally? Will NRF be acceptable to Europeans in later stages of its development?

The new National security strategy of the USA slightly mentions Europe and NATO. Fears that the USA might turn away from Europe started to go stronger on the other side of the Atlantics. The lack of military capabilities in European states makes the USA presence in Europe of the utmost importance. The easiest way to ensure this is via NATO. As NRF is often claimed to be the NATO's last chance, this initiative is undoubtedly important for Europeans. On the other hand, NRF also seems to be the cheapest way of rehabilitating European military capabilities, when with minimum of expenditures the maximal profit is obtained. NRF project is based on the concept of "niche capabilities", which means that NRF will be formed of special forces of the Allies that are to be trained together and rotate every six months. Those contributions are expected to decrease capability gap between the USA and European armed forces. Another very important advantage of the NRF is that this force is supposed to have common intelligence, common planning, $\mathrm{C} 2$ capabilities, exactly the ones, which are lacking in European armed forces. Moreover the very participation in the missions carried out by NRF will allow Europeans at least to be part of common decision making process, which would have not been possible if the USA tended to avoid NATO structures and rely on ad hoc coalitions. Thus NRF project is beneficial for Europeans.

Introducing the new USA National Security Strategy in West Point Military Academy G. W. Bush noted "Our security will require [...] a military that must be ready to strike at a moment's notice in any dark corner of the world. And our security will require all Americans to be forward-looking and resolute, to be ready for preemptive action when necessary to defend our liberty and to defend our lives." The National Security Strategy of the United States of America moreover states that NATO's core mission - collective defense of the transatlantic alliance of democracies — remains, but NATO must develop new structures and capabilities to carry out

\footnotetext{
${ }^{8}$ Quoted in: Kempin R., "The new NATO Response Force: Challenges for and Reactions from Europe", http://www.copri.dk/publications/Wp/WP\%202002/29-2002.doc.

${ }^{9}$ Smith D., " Preemptive Peace”, http://www.fcnl.org/issues/mil/sup/peacekeeping_force716-03.htm.
} 
that mission under new circumstances. NATO must bring forces to field, at short notice. Those forces should be highly mobile and specially trained.$^{10}$ Given quotations and the fact that NRF is essentially American proposal, is already a solid proof that NRF is beneficial for the USA. Nevertheless it is also worth mentioning that the USA already has capabilities to pursue complex military missions in faraway regions. It was verified during military operations in Afghanistan and Iraq. Why then the USA needs to develop the same capabilities in the structures of NATO? The answer to this question leads one to three interrelated factors. First of all, despite of decreasing significance of Europe in USA strategic thinking, Europe is still important for the US. NATO consequently is seen as a serious reason helping Americans "to stay in Europe". Secondly, when NRF starts operating, the USA will gain (though very minimal) support and reduce its operational costs. However the most essential achievement of the USA would be the legitimization of its military actions, which the USA failed to obtain in Iraq. Therefore it might be assumed that both the Americans and the Europeans are interested in NRF project and that both will make every effort to develop it.

Still, aiming to further analyze future perspectives of NRF several problematic issues are to be mentioned. First of all, in spite of solidarity showed up in Prague, fundamental differences still exist among NATO members and threaten to negatively influence further development of NRF. Armed forces aimed to fight terrorism have to possess at least a common definition of terrorism and consensus among the parties on the best ways to deal with it. However visions of dealing with main global challenges and threats vary in the USA and Europe a lot. Americans and Europeans often tend to even differently define those challenges and threats ${ }^{11}$. For instance, the regime of Saddam Hussein in the USA was perceived as posing a threat of terrorism, similar to the one experienced by Americans on 11 September 2001. The majority of Europeans on the other hand did not relate this regime to the threat of terrorism. Moreover Americans and Europeans did not agree on the means Americans have chosen to fight it. It might be presumed thus that NRF project will inevitably pose a dilemma in front of some NATO allies (e.g. France and Germany) concerning the understanding and assessment of preventive military actions and terrorism. Yet another significant disagreement between Europeans and Americans is related to the difference in views toward so called "rogue" states. The USA views them as failing to comply to the requirements of international law and seeks to isolate them. Europeans, contrary, think that integration of those countries into the international community is a mean to solve all their problems. Until those disagreements are overcome it is likely that contradictions between the USA and the EU regarding NRF will grow stronger. Meanwhile the hottest disputes in the domain include the discussions on the conditions under which the NRF is to be deployed.

The second group of problems is directly related to military capabilities. NRF designers fear that political leaders will tend to see NRF as panacea and will demand of it more than those forces are capable of.

\footnotetext{
${ }^{10}$ The National Security Strategy of the United States of America, September 2002.

${ }^{11}$ Van Ham P., Kugler R. L., "Western Unity and the Transatlantic Security Challenge", Marshall

Center Papers, http://www.marshallcenter.org/CISS/English?Mcpapers, p.20.
} 
Success of NRF will certainly depend also on the creation of proper decisionmaking structures. According to the project decisions on NRF deployment (when possible) is to be taken by the North Atlantic Council (NAC), in other cases - by NATO Defense Planning Committee, which France is not a part of. The French therefore are strictly against this option and propose that decisions should be taken exclusively by the NAC. However granting the NAC with exclusive decision-making powers in all cases would inevitably slow down the time of deployment and cause ineffectiveness of NRF. Cmdr Dick Lacey even suggests of granting SACEUR with a right to plan mission before the political agreement is reached..$^{12}$ Decision-making in capitals may be even more complicated. Aiming to deploy NRF each state will have to authorize its decision following the procedures envisaged by national laws. It is worth asking therefore whether slow procedures of legitimization of deployment carried out by national parliaments would not become the factor paralyzing actions of NRF?

It was agreed in Prague Summit that NRF would reach its initial operational capability as soon as possible but not later than October 2004, and its full operational capability not later than October 2006. 8-9 October 2003 in Colorado Springs (United States) NATO ministers of defense, chiefs of defense and NATO ambassadors convened for the first time to examine how new NRF might deal with future asymmetric threats such as terrorism and weapons of mass destruction (WMD). After the meeting Lord George Robertson tated that the ultimate message of the October 8-9 meetings was that alliance transformation will require "real deployable soldiers, not paper armies and that seminar led the political and military officials to a common set of understandings, for instance, that future crises facing NATO will require prompt decision-making in members' capitals and that advanced planning, including establishing rules of engagement, can help expedite responses. ${ }^{13}$ On 15 October 2003 the rapid response force was formally launched.

Despite the comon interest in NRF project and the very fact that NRF has already been launched, still many questions regarding the future perspectives of this project remain open. Will NATO be able to carry out operations extending its geographical limits? What kind of missions will it take? Is it possible to accelerate decision-making in NATO (this becomes especially important after the NATO enlargement)? What will be the relations between NATO and other international organizations, especially between NATO and the EU? Finally, what will be the USA standpoint towards NATO: will the USA see NATO as the pool of tools which the USA might use while constructing various coalitions or will cooperate with NATO as valuable organization enjoying the advantages of permanent cooperation structures.

12 2-4 July, 2003 - visit to the UK by the Defense and Security Sob-committee on Transatlantic Defense and Security Co-operation, http://www.naa.be/default.asp? shortcut $=406$.

${ }^{13}$ Porth J. S., "Robertson says NATO transformation must be completed" Washington File, 8 October 2003, http://usinfo.state.gov/usinfo/products/washfile.html. 


\section{The development of the EU Rapid Reaction Force (ERRF)}

In 1991 the EU Common Foreign and Security Policy (CFSP) and its military dimension (ESDP) was formally introduced at Maastricht European Council..$^{14}$ Introduction of the military dimension was in a way a response to the accusations from American side regarding the European military feasibility, on the other hand it was also an eventual consequence of European integration, a necessity for growing, widening and strengthening European Union to acquire new military and defense instruments aimed to protect values and interests of the EU abroad. The EUhas ceased being simply an economic or political block and became a security organization.

Since Maastricht development of military dimension in the EU has been proceeding very slowly. Until 1998 no principal decisions in the domain have been taken. Main factors preventing this initiative from further development was inability of the EU countries to find a common view towards the core issues of common defense policy and common defense and diverging opinions regarding the future of the EU - NATO relations. Finally, during British - French summit, which was held 3-4 of December 1998 in St. Malo agreement on the establishment of independent EU military capabilities to be used for essentially crisis management tasks was reached causing a principal break-through in the process of the EU Common Security and Defense Policy formation.

In 1998 in Cologne it was decided to incorporate functions of the WEU into the EU structures. ${ }^{15}$ Headline Goal was introduced in Helsinki together with an agreement on ERRF, the status of which was defined in the Treaty of Nice in $2000 .{ }^{16}$ In Laeken ERRF was already announced as capable of overtaking some crisis management operations. ${ }^{17}$ In May of 2002 for the first time crisis management training was conducted in the structures of the EU, which has received a very positive evaluation in the European Council of Seville in 2002. Despite obvious problems in the fields of air-lift, intelligence systems, special operations, search and rescue tasks, and, finally, protection against chemical, biological and radiological attacks ERRF was recognized as operable, therefore enabling Copenhagen European Council to adopt decisions to fully overtake peacekeeping missions in Bosnia and Herzegovina and FYROM from NATO. Europeans have already taken over the mission in FYROM, and by the end of 2004 plan to proceed with Bosnia and Herzegovina. In the summer of 2003 the EU mission ARTEMIS, consisting of more than 1500 soldiers and is aimed to protect civilians UN personnel, to improve humanitarian situation, to ensu-

\footnotetext{
${ }^{14}$ The Union shall set itself the following objectives: [...] to assert its identity on the international scene, in particular through the implementation of a common foreign and security policy including the eventual framing of a common defense policy, which might in time lead to common defense. Treaty of EU, Maastricht, 1991, http://europa.eu.int/eur-lex/en/treaties/dat/EU_treaty.html.

${ }^{15}$ Cologne European Council, Presidency Conclusions,1999, http://europe.eu.int/council/off/conclu/ index.htm.

${ }^{16}$ Treaty of Nice, Brussels, 2001, http://europa.eu.int/comm./nice_treaty/index_en.htm.

${ }^{17}$ Laeken European Council Presidency Conclusions, 2001, http://europe.eu.int/council/off/conclu/index.htm.
} 
re security of the refugee camps and airport and, to stabilize security situation in the DRC has been introduced in the Democratic Republic of Congo (DRC).

Headline Goal ${ }^{1}$

To establish until 2003 European armed forces able to undertake Petersberg tasks.19. These armed forces will consist of 15 brigades: 50 000-60 000 soldiers deployable in crisis area no longer than in 60 days and sustainable there not less than one year (without any rotation).

Relatively fast evolution of ERRF let one to believe that this project would be successfully implemented. However aiming to outline the perspectives of ERRF further development several problematic issues are to be discussed. The solution of those problems in one way or another will un-doubtfully determine whether ERRF would become effective instrument in ensuring, at least regional security, or would remain just a "paper project".

One of the main problems challenging the efficiency of the future ERRF operations is ambiguity of Petersberg tasks in both territorial and content senses. Until the EU solves this problem, limits and character of ERRF future activities remain unclear. Scenarios of the EU defense capabilities deployment have been discussed since 1995 with the possible longest distance from Brussels defined in terms "from 2000 to 6000 kilometers"20. That means that the closest deployment of ERRF may not extend the Eastern borders of the enlarged European Union, and the most distant ones - may reach countries like Afghanistan, Middle East region, or Africa. The inability of the Europeans to reach a common decision on more precise definition of Petersberg tasks leads yet to another problem - the issue of the EU identity. The EU will not be able to have Common Security and Common Defense, unless its members will have common values and interests.

Due to the diverging interests of member states and different international commitments also intensity of the involvement in international politics, it might turn to be very complicating to outline an undisputed list of the EU interests. The role of the EU itself in international politics would also determine the content of this list. If the EU would tend to stick to the role of a regional player, Petersberg tasks would be limited to the coping with the EU internal security problems and ensuring stability in geographically proximate areas. And still this scenario due to the ongoing enlargement and approximation of instable regions does not provide one with a clear definition of the future missions of ERRF. On the other hand, the EU members as representatives of "western civilization" might be interested in preserving and promoting values of the liberal democracy and aiming to defend those values the EU members

${ }^{18}$ Helsinki European Council Presidencdy Conclusion, 1999, http://europe.eu.int/council/off/conclu/ index.htm.

${ }^{19}$ In 1992 WEU countries signed a Petersberg Declaration declaring their readiness to make available military units to implement so called Peterberg Declaration declaring their readiness to make available military units to implement so called Petersberg tasks containing humanitarian tasks, peace-keeping tasks and tasks of combat forces in crisis management. http://europe.eu.int/seadplus/ leg/en/cig/g4000p.htm.

${ }^{20}$ Croft S., "Guaranteeing European Security?: Enlarging Again", International Affairs 78 (1), 2002, p.102. 
may commit themselves to get involved in more faraway regions e.g. Middle East or Africa.

Dduring the past years the EU was more eager to use economic, political instruments rather than the military ones to protect its values. Thus a significant shift towards military instruments is slightly likely at least in the short run.

Taking into account the fact that growing economic power of the EU turns it into a global player, it is worth discussing the global scenario of the EU international involvement. This scenario would commit the EU to get involved in the military operations in the very distant regions. Still global scenario is the least likely to evolve in the nearest future. First of all the economic power of the EU is not supported with adequate political influence and military capabilities. Secondly, in the meanwhile the EU does not seem to be interested in playing a more global role. Finally, it is obvious that protection of the EU interests on the global level is possible only if the interests of all members are defined in common, while in reality major differences among the EU members exist. In the short run therefore the most likely scenario is the one of a regional player. Until the EU would decide to take over more global responsibilities it still has to solve certain internal and regional problems. On the other hand, in the longer run successful integration and enlargement may undoubtedly push the EU towards more global ambitions.

The content of Petersberg tasks does not either provide one with clear answer to the question what kind of operations are envisaged for ERRF. Present definition of Petersberg tasks may even includebig scale conflicts such as Gulf War. It is likely that the contents of the future missions of ERRF will depend on whether aiming to solve problems of international security the EU would choose to rely on a military or civilian role.

Henrik Larsen argues that the EU concept of dealing with international conflicts is linked to a liberal doctrine, which is prevailing in the EU. Europeans attach major importance to the respect of human rights, principal freedoms and supremacy of law. ${ }^{21}$ The EU tend to relate causes of the contemporary international conflicts to the violation of those principles and think that the restoration of major principles of democracy might solve the majority of those conflicts. For instance, the Europeans define terrorism as a problem of economic, political or/and social nature, which demands corresponding means to deal with it. The USA on the other hand, sees terrorism as a military threat and is convinced that the best means to fight it are those of military origin. Thus one of the principle missions of the EU - to ensure international security and respond to the contemporary security challenges - is based on the civilian instruments. The EU identifies itself with a civilian player. Dr. Javier Solana once has stated that "stability of the World is more "civilian" than "military" concept", and the main goal of the EU should be the role of a "civilian power". Therefore one of the most important guarantees of security and stability according to Dr. J. Solana is the continuity of integration and the successful enlargement. ${ }^{22}$

\footnotetext{
${ }^{21}$ Larsen H.” The EU: A Global Military Actor", Cooperation and conflict, Journal of the Nordic International Studies Association, SAGE publications, Vol. 37, N. 3., September 2002, p.291.

${ }^{22}$ Ibid., p.298.
} 
Although preferring civilian conflict management instruments in general the EU views problems in the immediate neighborhood as an area of its special political responsibility. Europeans tend to directly relate their obligations and success in Balkans with their security therefore not hesitating to use their military instruments in the region.

Military instruments in the EU are viewed just as one of (and probably not the most important) the means to ensure security. Europeans tend to incorporate them into a wide net of political and economic means. Christopher Patten when speaking about the changing problematique of security has stated that although „smart” bombs are important but not as important as smart aid for development. More important is the aim to involve states in the international community than isolate them. ${ }^{23}$ The same ideas might be found in the speech delivered by Dr. J. Solana on 20 June 2003 in Thessalonici A Secure Europe in a Better World ${ }^{24}$, which eventually have become a security strategy of the EU. It emphasized three major goals: first of all, to ensure more resources when creating economic an political stability in the neighborhood; secondly, to support and strengthen multilateral international order; and, finally, to strengthen civilian and military capabilities to fight with the threat of weapons $f$ mass destruction and "rogue" states. Civilian instruments were awarded with special attention. The speech also underlined the significance of preventive actions, though with a strong emphasis on multilateral world order and hardly mentioning preventive military strikes.

Having in mind that meanwhile the EU is preoccupied with mostly regional problems and seeks to solve them first of all by using civilian instruments with military means tightly embedded into the wide civilian complex of various instruments, it is likely that in the short run Patersberg tasks will be defined as peacekeeping operations of very limited scale carried our in Europe or not far away regions.

The problem of Petersberg tasks' definition is closely related yet to another factor, which will evidently have an essential impact on the future success of ERRF the lack of military capabilies. Although the majority of ERRF experts claim that capabilities' problem is the critical one to the success of ERRF, but the article argues that the impact of this problem on ERRF will depend on the definition of Petersberg tasks. Insufficiency of certain capabilities would not be that evident if the EU members decide to adopt the narrowest definition of Petersberg tasks.

Major problems of European military capabilities have revealed in Balkans. In the presentation of the former Defense Secretary of the USA W. Cohen and Gen. H. Schelton presented to the Armed Forces Committee of the Senate the European and American joint operations have received quite a negative assessment. ${ }^{25}$ Indicating major problems Americans summed up that due to the ineffectiveness in mobility, command, control and communication the European armed forces are facing

${ }^{23}$ Freedland J. „Patten Lays into Bush's America“, The Guardian, February 9, 2002.

${ }^{24}$ Solana J. "A Secure Europe in a Better World", Thessaloniki, March 20, 2003. The project on 12

December 2003 was adopted by the European Council as European Security Strategy. http:// ue.eu.int/uedocs/cmsUpload/78367.pdf.

${ }^{25}$ Evidence from Smith I. D. Shadow Secretary of State for Defense, United Kingdom to the Committee on International Relations, House of Representatives, Wednesday, 10 November, 1999. 
heavy difficulties. Conflicts in Balkans have demonstrated serious deficits in the fields of strategic intelligence, anti-missile defense, strategic transportation, air capabilities, precision guided missiles and other areas related to the modern technology. Lack of those capabilities is also recognized by Europeans themselves. The Chair of the EU Military Committee is convinced that ERRF will not be able to ensure effective air transportation untill 2008 - 2012 when the first A400M starts operating and utntill then Europeans will not be capable of carrying out more complex missions. ${ }^{26}$ Although majority of those capabilities are more relevant to the operations of territorial defense and large scale operations therefore the shortages in those fields may not have such a devastating effect on the Petersberg type of operations, if the EU decides to expand the framework of its involvement those capabilities will be indispensable.

In fact, the problem of capabilities was "programmed" with the introduction of Headline Goal, when the Europeans have wrongly calculated the real costs of its implementation. Taking into account the possibility that some of the missions might be dragged out or the EU might get involved in several missions at the same time, ERRF have to be able to rotate. Therefore aiming to take on more ambitious missions the EU will have to possess armed forces three or four times bigger than those stand-by 60000 forces envisaged in the Headline Goal. The real number of necessary forces may rise to 200000 respectively increasing amounts of technology, logistics and other capabilities. In spite of the fact that Defense Ministers of European countries have agreed upon the enlargement of their input in the November of 2001, their real ability to provide those capabilities is highly questionable.

Yet another factor that not only determines the backwardness of the EU military sector, but also increases the dependency of the EU member states on the USA - is the problems of the European defense industry. Fragmentation in defense industry structure, competing interests of member states and insufficient markets decrease the competitiveness of Europeans in the global market and has a serious impact on the autonomy of European defense industry. Although at least minimal foundations for the cooperation were already laid down during the Cold War: the establishment of European group and the Independent European Programme (which in 1992 were transformed into the Western European Armaments group in the framework of the $\mathrm{WEU})^{27}$, and all the EU members recognize the obvious advantages of cooperation if aiming to increase effectiveness of defense industry, the tighter cooperation in most cases is blocked by inconsistent interests of the EU members.

Some of the positive trends that have evolved in the European defense industry during the recent years deserve to be mentioned. Due to the strengthening position of the USA products in the European markets and increasing competition European companies have begun to merge at first at national level, but recently involving the

\footnotetext{
26 “Top military official predicts EU merge with NATO”, 17 January 2003, http://www.eurobserver.com/index. phtml? aid $=8090$.

${ }^{27}$ Cornish P., "Partnership in Crisis: the US, Europe and the Fall and Rise of NATO" Chatam House

Papers, London, Royal Institute of International Affairs, 1997, p.4.
} 
convergence of several leading companies on the European level. In 2002 Great Britain, Germany and Italy have established Organization for Joint Armament Cooperation (OCCAR), which is supposed to implement joint procurement programs and enable those countries to arrange joint contracts.

One of the possible solutions to the problems of defense industry in Europe is the harmonization of the technical standards of operations and reconciliation of commercial interests, which was already introduced in the field of aviation and space industry. It is likely, that international programs (Joint British German Multi Role Armored Vehicle Program, air defense program Horizon, Tiger, NH90 helicopter program, A400M) ${ }^{28}$, will give a positive impulse for the further development and restructuring of European defense industry. The creation of the joint European Armory, Research and Military capabilities agency, proposed in the project of the EU Constitution will undoubtedly prompt the development of the EU military capabilities and will positively influence interoperability among members, respectively strengthening basis of the EU defense industry. On the other hand, member states are afraid that if this agency has the right to take decisions on the principles and priorities of procurement it might endanger vital interests of certain countries or existing trade relations with the third states.

The future success of ERRF will also depend on the ability of the EU to ensure sufficient financing of armed forces and particular operations.

In 2003 European NATO members have spent 200039 million USD for the defense, while the USA - 383720 millions USD respectively ${ }^{29}$. If comparing the Europeans and the USA it should be mentioned that not only the defense spending was considerably less in Europe than in the USA, but also the main part of the resources in Europe have been allotted to sustain the armed forces, when in the USA it is devoted for the development of modern military technologies. Insufficient and ineffective financing of armed forces may determine that the EU armed forces experiencing serious shortfalls will not be able to carry out the operations of even very limited scale.

The ability to finance particular military operations will also have an impact on the evolution of ERRF. Complicated and time-consuming procedures of financing in the EU can slow down the course of operations. Insufficient financing may have even graver consequences, when the inability to find necessary resources manifests itself already in the course of operation. It may endanger safety of soldiers and cause serious stability and security problems in the region. Financing procedures of the missions in the EU may be basically divided into two parts. The first one is civilian, which is devoted a separate row in the EU budget. The second one is military that is constructed on ad hoc basis. Financing of Petersberg tasks, with the exception of administrational, logistical and medical costs, is going to come from the member states and will be based on the same formula as the one applied in NATO, when all the costs are being covered by countries that participate in the operation. ${ }^{30}$ The same

\footnotetext{
28 "Europe in Space: Overtaking the Cold Warriors" 1900 GMT, 19 April 2001, http://www.stratfor.com.

${ }^{29}$ Defense expenditures of NATO countries, http://www.nato.int/docu/pr/2003/table1.pdf

${ }^{30}$ Missiroli A., "Euros for ESDP: financing EU operations", Occasional Paper N.45, June 2003,

European Union Institute for Security Studies, Paris, http://www.iss-eu.org/occasion/occ45.pdf.
} 
mechanism is quite successfully functioning in NATO, however due to the principle of "constructive abstention" 11 it might impose serious free riding problems on the EU.

Another problematic issue is the complexity of the EU structure. Implementation of Petersberg tasks will request from the EU members a wide range of different instruments, which belong to the "responsibility" of different EU pillars. The sources and procedures of the financing of those instruments will also differ. ${ }^{32}$ On one hand, variety of sources and procedures undoubtedly slows down the course of operation and reduces effectiveness of the mission. On the other hand, it is very difficult to guarantee that all the financial means a received when necessary. Moreover the imperfectness of financing might cause uneven distribution of costs, when the bigger states bear the lion's share not only in the sense of personnel but also of financial costs. The complicated procedure of financing military operations therefore becomes both the cause and effect of the civilian identity of the EU. On one hand, due to the peculiarities of financing mechanism it is easier to use the civilian means of crisis management. On the other hand, existing mechanisms show which instruments of conflict resolution are given priority.

Although a wise solution of capabilities problems may become a turning point in ERRF development the article argues, that there are even more important factors that are blocking the evolution of ERRF, CSDP and even CSFP and which would be even more difficult to tackle. In fact insufficiency of military capabilities could be fixed up over the time with the help of strong political will and fruitful efforts of member states. It is far more difficult to manage the problems stemming because of the diverging national interests. The EU members are not able to reach an agreement even on the shape of the EU: some of them see the EU as federation, the others - as confederation. Another dividing line is the relationship with the USA. If the EU members cannot agree even on such fundamental questions and general vision of ERRF it might become yet more difficult to find a common decision on when, how and where ERRF should be deployed.

Aiming to ensure unified and common defense policy in the EU well established institutional basis providing the background for the harmonization of diverging interests and binding commitments would be advantageous for further development of ERRF. But the CFSP, which ERRF is a part of, is based on the principles of intergovernmentalism and unanimity and therefore does not provide any consolidating framework. The introduction of majority vote in CFSP would certainly have a positive effect on the effectiveness of ERRF, though member states have fears that majority voting on important issues of foreign and security policy may violate their national interests. Those fears prevent them from refusing the unanimity. Despite several initiatives to embed the principles of inter-governmentalism and unanimity in the

\footnotetext{
${ }^{31}$ Amsterdam Treaty envisages principle of abstention (or constructive abstention) that enables member states, which feel that certain decision of the EU may contradict with its national interests, to refrain from participating in implementing this decision, but not blocking the adoption of the decision and recognizing its validity.

${ }^{32}$ Missiroli, (note 30).
} 
new EU Constitution, in the final project of Constitution the right to decide on the issues of CSDP in crisis situations (including the decisions to carry out Petersberg tasks) is again assigned for the Council of the EU in which decisions are to be taken unanimously.

The integration of new members may complicate the ability to reach an agreement concerning ERRF even more. First of all, these countries are different from the old members in several aspects: their economic capacity is much worse than that of the Western Europe; they are more "sensitive" that concerns sovereignty issues, usually they are more pro-American than the rest of the enlarged European Union. On the other hand, with the inclusion of the new members borders of the EU will expand to the problematic regions thereby extending definition of possible ERRF missions. Having in mind the particularity of region it is obvious that there will be a large gap between the interests of the old and the new members and among the latter in the variety of areas. It is likely that the enlarged EU will also face the problem of different threat assessment. It is evident that it will become extremely hard to reach a compromise in the enlarged EU under those circumstances

The EU Constitution project introduced several improvements related to the CSDP: expansion of the definition of Petersberg tasks including such issues as disarmament, aid of military experts, functions of stabilization of the conflict and fight against terrorism (including support to the third countries when fighting the terrorism on their soil). The project has also proposed to include the principle of "structured cooperation" enabling certain countries to enhance their defense cooperation and to ensure the possibility for ad hoc coalitions in the structures of the EU to act in the name of the EU. Other proposals include "solidarity clause" (that would commit the EU members to help each other in the case of terrorist attack and in the case of natural or human maid catastrophe) and establishment of European Armaments, Research and Military Capabilities Agency. ${ }^{33}$

Those provisions of the EU Constitution would help to solve at least a part of ERRF problems. But the discussions on the draft Constitution have once again revealed the incompatibility of the members' visions towards the future of ERRF, which will probably become even more serious after the enlargement.

Disagreements among the EU members towards the development of ERRF were obvious during the summit of four member states on the defense cooperation (Belgium, France, Germany, and Luxembourg), which was held on 29 April 2003 in Brussels. The summit has proposed the introduction of solidarity clause, principles of collective defense and structured cooperation, the extension of Petersberg tasks' definition (including the possibility for the EU to take on all the types of operations (peace and combat), establishment of a separate EU headquarters and the procurement agency. ${ }^{34}$ The proposals of the four have provoked a vivid reaction in other member states, with some of them openly expressing their dissatisfaction and appre-

\footnotetext{
${ }^{33}$ Draft Treaty Establishing a Constitution for Europe, Brussels, 18 July 2003, http://www.european-convention.eu.int/bienvenue.asp?lang $=\mathrm{EN}$.

34 "Meeting of the Heads of State and Government of Germany, France, Luxembourg and Belgium on European Defense”, Brussels, 29 April 2003, http://www.dgap.org/english/tip/tip0302/ ge_fr_lu_be290403.htm.
} 
hension. Italian and British officials were worried that those proposals may undermine the transatlantic link. Representatives of the EU institutions were also reserved in welcoming the initiative. Dr. J. Solana has noted that the summit of the four was valuable for the EU just in that sence if it aims to stimulate the members to allot more financial means for the development of military capabilities ${ }^{35}$, however neither of other proposals was ever mentioned. Roman Prodi affirmed that he supports the initiative only so far as it remains open to other members. Tony Blaire criticized the proposals of the four declaring that the Brits would not support any initiative that threatens to harm NATO or contradicts the fundamental principles of European defense that were agreed upon so far. He even warned of possible divisions of Cold War type if the firmness of transatlantic link is undermined. ${ }^{36}$

Positions of Great Britain, Spain, Portugal, Italy, Denmark and the Netherlands also clearly expressed the same idea: the domain of collective defense is to be left for NATO responsibility. Four other members of the EU (Finland, Sweden, Ireland and Austria) together with two candidates (Malta and Cyprus) pursue nonalignment policy therefore are also likely to ignore those proposals. The rest of the candidates, Lithuania among them, stand for the maintenance of transatlantic link and in their defense planning prioritize NATO. Finally the very fact that none of the EU representatives took part in the summit shows that the initiative of the four does not represent the official EU policy. Moreover although the participants of the summit were intending to seriously fight for their proposals in the Convent, not all of them were adopted. First of all, other big members (Brits, Italians, Spaniards, Portuguese) are not interested in them and openly declare the priority of NATO and devoting to the ESDP only the complementary role. On the other hand, France and Germany aiming to improve their relations with the USA, which were considerably corrupted during the Iraq campaign were not so insistant on some of their proposals.

In 2003 ERRF wes declared operable and is already carrying out missions in Macedonia and Congo. Those missions however are very small and uncomplicated but are especially important for the Europeans. The success would, first of all, help to regain confidence in the eyes of the USA, secondly, would prove to the World that political and economic ambitions of the EU are supported with adequate military instruments. Finally, the success of the Europeans in those missions will have an evident impact on the image of ERRF and their future evolution.

The future of ERRF will depend a lot on whether Europeans are successful in solving institutional and capabilities problems. And still the most important factor is neither institutional structures nor capabilities, but rather sincere concernment of the EU members in the issue. In the meanwhile it seems that member states lack political will to seriously engage in ERRF. Thus it is worth asking whether the EU members are willing and ready to risk the lives of their soldiers for the sake of Europe? If someone would ask this question now it is likely that the answer of the majority of member states would be negative. Therefore the real challenge that is faced by the European countries

\footnotetext{
${ }^{35}$ Lobjakas A., "EU: Defense 'Mini - Summit' Highlights Unease With U.S. Dominance”, http:// www.rferl.org/nca/features/2003/04/29042003164338.asp.

${ }^{36}$ Ibid.
} 
is their ability to ensure a clear and strong political will to have CSDP. In this respect the development of certain political and institutional culture that would be prompting the EU members to define their national interests in the perspective of the EU gains a special significance. It becomes more important than the efforts to establish the most proper voting system or even attempts to improve military capabilities.

Moreover ERRF is not possible if there is no effective CFSP. Member states have to not only have a common visions of ERRF and their deployment, they also have to decide in common on the place of those forces in regional security architecture including their relations with other international organizations, especially NATO. Most of the EU members tend to assign the principal role in the regional security system to NATO and would deploy their armed forces in the structures of the EU only if NATO refuses to take part in the mission. Therefore lots of uncertainties regarding the future ERRF mission still remain. It is also problematic that both the EU and NATO will essentially be using the same capabilities. The scarcity of capabilities in the EU will make ERRF dependent on NATO, especially in more complicated missions.

Development of ERRF may slowdown in a short run because of the EU integration and enlargement. On the other hand, if both processes will turn out to be successful it is likely that this would positively influence further development of ERRF. The world famous EU scholar Donald Puchala in his article Building Peace in Pieces: the Promise of European Unity notes: "Historically, the course of intra-European international relations in the context of the European Community and its institutional progeny is best seen as a series of problems constructively solved and a congeries of crises constructively weathered [...] almost every major goal (and countless minor ones as well) in the course of European integration to which Community members have committed themselves [...] usually later rather than sooner [...] get accomplished nonetheless." 37

Although the current development of CSDP and ERRF do not provide much root for optimism it might turn out that D. Puchala was right. Trying to solve internal and regional problems the EU will stick to the role of regional player in the short run and would probably pay less attention to ERRF or CSDP and CFSP in general. However in the long term the EU may seek for more global role and this certainly to bring it back to such issues as common foreign and security identity. A lot would depend also on yet another choice of the EU: whether it decides to base this identity on military or civilian instruments. This would certainly affect the future shape and prospects of ERRF.

\footnotetext{
${ }^{37}$ Puchala D., "Building Peace in Pieces: the Promise of European Unity" in Kegley Ch. W., Wittkopf E. R. ed., The Global Agenda: Issues and Perspectives, Boston: McGraw-Hill, 1998, p.171.
} 


\section{NRF and ERRF: prospects for cooperation and major problems}

Inter-organizational cooperation has become one of the principal features of security structures after the Cold War. ${ }^{38}$ That means that the most popular way to organize the functioning of security structures was to rely on the principle of labor division, when different international organizations are providing necessary security instruments in all dimensions of security policy. The fact that the EU is able of carrying out just very limited missions without the support of NATO, also that the majority of the EU members also belong to NATO and that variety of historical, political, economic and cultural ties connect those organizations and their members and foremost that both organizations are working for the same sake: promoting democracy and ensuring security and stability all over the World, make the cooperation between two organizations inevitable.

Relations that existed between the North Atlantic Alliance and the Western European Union (WEU) might be called pre-history of NATO - EU cooperation. Article 4 of Modified Brussels Treaty has committed parties of the Treaty and all the organs created by the Treaty to closely cooperate with NATO, rely on NATO military command, information capabilities and to consult with NATO on various military issues. ${ }^{39}$ Joint agreements and institutions created by NATO and the WEU since 1991 to 2000 have laid the foundations for the development of the EU - NATO strategic partnership. After the EU took over the functions of the WEU the need to reestablish relations between NATO and the EU emerged. The solution was introduced in Washington summit ${ }^{40}$, and proposed that both organizations should cooperate relying on the framework, which used to exist between NATO and the WEU. In July 2000 regular preliminary discussions on cooperation have started. In Nice European Council permanent NATO and the EU cooperation structures were approved. The EU access to NATO capabilities was among the most important though also the most controversial issues in the debate on the EU - NATO cooperation. This access was proposed in Nice to be based on the "Berlin plus"41 formula. Although in NATO ministerial meeting, which was held 14-15 December 2000, majority of NATO mem-

\footnotetext{
${ }^{38}$ Winn N., „Europe: Old Institutions, New Challenges“ in Jones C., Kennedy-Pipe C. ed., International Security in a Global Age: Securing the Twenty - first Century, London, Portland: Frank Cass Or., 2000, p.80.

${ }^{39}$ Modified Brussels Treaty, Brussels, 1954, http://www.weu.int/Treaty.htm.

${ }^{40}$ Washington Summit Communiqué "An Alliance for the 21st Century", North Atlantic Council, Washington, D.C., 24 April 1999, http://www.nato.int/docu/pr/1999/p99-064e.htm.

${ }^{41}$ Decisions adopted in Berlin in 1996 envisaged to cover NATO support for operations led by the WEU, known as the "Berlin arrangements". In 1999 new arrangements for the EU ("Berlin Plus") were agreed upon. The "Berlin Plus" package consists of four elements: 1) assured EU access to NATO operational planning, 2) presumption of availability to the EU of NATO capabilities and common assets, 3) NATO European command options for EU-led operations, including DSACEUR, 40 adaptation of NATO defense planning system to incorporate availability of forces for the EU operations, http://www.nato.int/uk.docu/esdi.htm.
} 
bers approved the structures introduced in Nice, decision was not adopted because Turkey, fearing that ERRF might be used against its interests (for instance, in Cyprus) vetoed the initiative in the NAC.

Greece was also precautious regarding cooperation between NATO and the EU. Doubts of Turkey and Greece have prolonged further development of the EU NATO relations for yet another two years. The agreement however was finally reached at the summit of Copenhagen European Council. Turkey succeeded to include into the agreement the notion that in the EU crisis management operations can participate only those EU members that are also NATO members or partners, thereby "excluding" Malta and Cyprus. 13 December 2002 NATO and the EU members have announced joint Declaration on ESDP. ${ }^{42}$ This declaration has outlined the formal principles of the EU-NATO cooperation and provided the EU with the assured access to NATO planning (the EU will be able to make a use from SHAPE operational planning and NATO capability planning process) and logistical capabilities in the case of crisis management or conflict prevention. Principle of NATO primacy incorporated in the WEU declarations, which had been attached to the Treaties of Maastricht and Amsterdam, was confirmed in Nice and the Declaration on ESDP. ${ }^{43}$ Both Declaration on ESDP and an agreement on the security of information concluded between the EU and NATO enabling both to exchange secret documents, have made possible for the EU to take over from NATO the mission in FYROM on 31 March 2003 and confirmed strategic partnership of two organizations.

Still the endorsement of this principle leads to the conclusion that ERRF will participate only in those missions, which would be refused by NATO. Thus it is worth asking whether agreements between the EU and NATO mean that the organizations have agreed on the division of functions in ensuring security and stability in the World? And, if yes, what roles were envisaged for ERRF and NRF? Finally, it is still unclear if system of cooperation proposed by "Berlin plus" formula is realizable in practice?

Former NATO Secretary General George Robertson has noted that the principal aim of NATO in the domain is to ensure that NRF and ERRF would complement one another. The Secretary General is convinced that those forces will not duplicate each other and have good opportunities for cooperation. According to him ERRF differs essentially from NRF, first of all, because it will not include American soldiers, and secondly, because both forces have different objectives. The main objective of ERRF - is the implementation of the Petersberg tasks. The key mission of the $\mathrm{NRF}$ - is to douse fire in the World's hot spots. ${ }^{44}$

Chairman of the EU Military Committee Gen Gustav Hägglund during his visit to Finland talking about principal challenges in contemporary security has emphasized disability of the EU to assure rapid response to major contemporary security

42 "EU-NATO Declaration on ESDP", 13 December 2002, http://www.nato.int/docu/pr/2002/p02142e.htm.

${ }^{43}$ Missiroli A., "Flexibility and Enhanced Cooperation in European Security Matters: Assets or Liabilities", Occasional Paper N.6, January 1999, European Union Institute for Security Studies, Paris, p.40.

44 "Robertson: EU is "flabby giant" not "pygmy", 8 October 2002, http://www.euobserver.com/ index.phtml? aid $=7845$. 
challenges. He noted that the EU lacks necessary institutional structure to implement those tasks and therefore emphasized that new missions are to be carried out by $\mathrm{NRF}$, which could provide rapid and effective reaction. If necessary the EU may take over the initiative in later stages of the conflict. ${ }^{45}$ In the Join Declaration of the EU and NATO the emphasis was also laid on the different character of both organizations underscoring that the EU is to take part only in those missions, in which NATO will not collectively participate. It is obvious thus that NATO and the EU rapid reaction forces are meant to be different and undertake different functions and therefore it is likely that those forces will not duplicate each other in future. On the other hand, although the division of functions would be the most rational solution, it still unclear if it is realizable in reality. Moreover it is also uncertain if all the participating countries are interested in this division.

ERRF is already declared operable and has started its first missions in FYROM and Democratic Republic of Congo. Still this force is capable of undertaking operations of only very limited scale and the final result of its evolution is vague. NRF was declared operable on 25 October 2003 however, in a way, it is still a project, which not having practical evidence of certain operations is very difficult to evaluate. Nevertheless, several problem groups that might harm operation and cooperation of both forces are already becoming visible. The main problems as in the cases of NRF and ERRF individually might be divided into two blocks: capabilities and political will.

It is usually argued that the most obvious are the capabilities problems of which the principal one is a "double hating" ${ }^{46}$. Although both the EU and NATO officials acknowledge that ERRF and NRF are intended to undertake different missions therefore would not compete for the same capabilities, it is worth noting that limited amount of soldiers and necessary resources will exists at the time for all types of operations. Is it possible then that Europeans fighting under NRF helmets in the initial stages of the conflict would change them into ERRF uniforms and proceed with the peacekeeping mission? Several operations although of a very different character being carried out at the same time would inevitable raise the issue of the insufficient resources. The same air transportation capabilities might be needed in peacekeeping or humanitarian operations as well as in more intense operations. Capabilities and resources used by ERRF would not be accessible for NRF and vice versa. Moreover as functions and fields of activities of ERRF and NRF are not clear defined and might be expanded in the future (the introduction of battle groups in the Eu is one of the examples), competition over the resources might not only become a serious obstacle for effective operation of both forces but also can become a threat for the international security.

It is still not clear weather Europeans, which are facing serious problems regarding the financing of defense, are capable of ensuring necessary capabilities for NRF. Although it is presumed that NRF would rely on "special capabilities" therefore would not demand additional expenses the danger remains that all the problems faced by ERRF might migrate to NRF. Moreover, European countries will be obli-

45 "EU needs NATO's new Response Force", http://www.euobserver.com/index.phtml?aid=8090.

46 "Double hating" means that both NRF and ERRF would use the capabilities from the same pool of resources. 
ged to relocate their defense expenditure orienting it toward more particular and important areas (which was not the case with ERRF) and, it is likely that additional resources would be needed for those reforms. If Europeans fail to ensure sufficient military capabilities and respective financing, both projects would be condemned for failure. One has to take into account distributional problems of defense expenditure, which are stipulated due to the varying interests of member states. It is slightly likely that interests and costs would coincide in all the cases.

Joint Declaration of NATO and the EU envisages that NATO and the EU will share modern technologies and other costly military resources. On one hand this would solve the problem of needless duplication on the other hand the implementation of this intention in reality is doubtful. First of all, management of the advanced technologies requires appropriate preparation - therefore borrowing of expensive modern capabilities will include borrowing of personnel, or special training is to be organized in every particular case. It is possible that some members of one or another organization would not agree to lend the expensive equipment or their soldiers to others and would veto the decisions therefore thwarting or retarding the course of operations. Communicational and information sharing possibilities between two might turn out to be even more problematic. In Bosnia and Kosovo even in the framework of a single organization it was extremely difficult to coordinate the actions of Europeans and the USA, or even among the Europeans themselves. One can only imagine the hardships that might arise with all those various countries participating in the structures of two organizations. It is likely therefore that problems of interoperability and insufficient military capabilities that are relevant for the NATO structures would be aggravated if the EU and NATO would act jointly.

It is expected that NRF project would oblige Europeans to increase their military capabilities and that due to the fact that capabilities are the same this would be advantageous for both NRF and ERRF. It is worth asking though if the problem of interoperability and insufficient capabilities does not condemn both projects to the failure? Whether member states would be interested to lend their military capabilities in missions, which they would not be interested in? Having in mind that security concepts in Europe and in the USA differ a lot, moreover that interests of Europeans also diverge, this could provoke serious challenges for the future evolution and operation of NRF and ERRF.

Problems related to the military capabilities although often more visible are possible to solve over the time (the same as in the case of ERRF) if member states are interested in their solution. Political problems, on the other hand, although in most cases are less visible, usually are more complicated to tackle.

The future of NRF and ERRF cooperation will inevitable depend on the status of transatlantic link. During the Cold War a firm transatlantic link was the main guarantee for the security in Europe. Security interests of European countries were subordinated for the security orientation of dominating power (the USA). The latter as a reward deployed its armed forces thereby ensuring security of the Western Europe. After the end of the Cold War relations between allies in Europe and the USA are constantly challenged by the increasing amount of the disputes. This tendency provokes worries on both sides of Atlantic - if the new world order does not threaten to ruin long-term partnership? Weakening transatlantic link may cause dec- 
rease of NATO significance therefore making NRF meaningless. In that case the USA might take over the tasks envisaged to NRF. This scenario would inevitably have negative effect also on the evolution and operation of ERRF, which is dependent on NATO capabilities.

Ronja Kepmin is convinced that eventually NRF and the ERRF would become incompatible, ${ }^{47}$ because they are based on essentially different security concepts related to discrepant standpoints towards the possibilities of cooperation, diverging interpretation of international law, varying definitions of major threats and respectively differences in choice of the instruments to respond to them. Characteristics of the American and the European security concepts were comprehensively outlined in the article "Power and Weakness" by Robert Kagan. ${ }^{48}$ The fact that NRF is based on security logic of the USA presents Europeans with three principal questions, the answer to which would in substance determine the perspectives of NRF. First of all, if those countries are willing to globally fight with asymmetric threats (international terrorism and weapons of mass destruction), employing preventive actions if necessary? Secondly, are they ready to change their current political style into more active involvement? Are they ready to ensure sufficient resources necessary for the operations overextending the frontiers delineated by the 5th Article?

ERRF, on the other hand, is based on the European security vision, which might be linked up with the civilian mission of the EU and long-term conflict prevention. In the case of conflict the EU seeks to be capable of acting rapidly, but lays the emphasis on civilian capabilities (police, judges, civilian institutions). The USA contrary to the EU almost did not pay any attention to those capabilities in its strategy on Iraq. Having in mind that NRF is designed to undertake operations similar to the one carried out in Iraq, it is obvious that the European and the American visions on how to respond to the threats might diverge. Moreover considering philosophical differences regarding the issues of foreign policy that exist between the USA and European countries, important challenges could arise due to the inability to agree where and what forces are to be deployed.

It is also worth noting that institutional structures and decision making in the CSDP are very complicated and too slow in the case of crisis, therefore ERRF will be able to participate only in the operations of very low intensity. Moreover the ability of ERRF to undertake independent mission might be reduced by the principle of NATO primacy. If Americans would tend not to take European security concept into account this might again increase tensions between the two.

The problem might be solved by transplanting the European security concept related to peacekeeping into the structures of NATO, which are better adjusted to search for compromises and where political ambitions are based on real military power. Gen Gustav Hägglund thinks that European pillar in NATO and ESDP will be merged eventually. During his visit to Finland he was convinced that if Finland does not join NATO till the end of the current decade it would not make sense to do

\footnotetext{
${ }^{47}$ Kempin, (note 8$)$.

${ }^{48}$ See: Kagan R., "Power and Weakness", http://www.policyreview.org/JUN02/kagan_print.html.
} 
it later, because the ESDP and European pillar of NATO will be the same. ${ }^{49}$ If it is really to happen depends on both the ambitions of Europeans to posses at least partly independent armed forces in the EU structures and also on the USA position regarding the European security concept: is it nonetheless estimated as simply an expression of European weakness or is it taken seriously and involved in the construction of common security strategy? Will the EU states that see the project as a possibility to strengthen the EU identity and potentially defend the EU interests, would be determined to refuse ERRF? It is worth therefore noting that if Europeans are really interested at least in partial autonomy of CSDP and CSFP ERRF has to operate at least partly independently from the USA and NATO. On the other hand, the principle of NATO primacy and the USA striving to dominate decisions on both NRF and ERRF deployment might decrease interest of European allies to be part of those missions. It may also happen if Americans would see NRF as simply being an instrument to legitimize their global interests and construct capabilities for their missions.

NATO's right of the "first response"is also widely discussed. The principle envisaged in the documents outlining the NATO-EU cooperation would allow avoid disputes over the leadership in the case of crisis and would also force Europeans to increase their military capabilities. However it may have negative effect on transatlantic relations. The problem lies in the fact that not only functions would be distributed between NRF and ERRF, but possibly also missions. NATO is likely to be entrusted with the military domain of the campaign on terrorism, while leaving civilian domain (probably including some military aspects) to ERRF. Americans are worried that this division would create a two-level structure, in which Europeans would only undertake very easy tasks (peacekeeping) thereby leaving all the hardest and "hottest" work for NATO or as to be more precise for the modern armed forces of the USA. ${ }^{50}$ Former the USA Ambassador to NATO Robert E. Hunter in his publication "ESDP: NATO partner or competitor?" outlines recommendations for the successful and effective operation of NATO and the EU. First of all he emphasizes the importance of the principle of NATO's primacy and then tries to draw the attention to the destructiveness of the formal or informal labor division between NATO and the EU. ${ }^{51} \mathrm{He}$ is convinced that any labor division should be refused with all the military capabilities and costs being common. Both organizations, according to him have to cooperate when fighting with the terrorism and try to encompass different aspects of security policy (military, political, diplomatic intelligence, financial and judicial). ${ }^{52}$ Nevertheless taking into account diverging security concepts, which on NRF and ERRF are based practical implementation of those recommendations is hardly possible.

Europeans in their turn feel concerned that NRF might be used by Americans just as the instrument to construct necessary capabilities for the missions that Ameri-

\footnotetext{
49 (note 26).

50 “Amerikiečiams nerimą kelia Europos Sajungos siekiai kurti savarankišką gynybos organizaciją" Laisvoji Europa, 20000313.

${ }^{51}$ Hunter R. E., "The European Security and Defense Policy: NATO's companion or competitor", 2002, http://www.rand.org/natsec_area/products/MR1463.html.

${ }^{52}$ Ibid.
} 
cans are interested. The Europeans fear that the USA would tend to participate in the operations selectively and more seldom, therefore leaving all the long-term lowintensity politically insignificant though very expensive tasks for Europeans. By granting NATO with the right of first response the autonomy of the EU to decide on the issues, which in fact are the most important ones - to decide on the use of power - is decreased or totally negated. If decisions are to be adopted in the NAC, the USA will have a veto right on ERRF deployment and ERRF would really become just a European pillar of NATO. Responding to the limiting of their sovereignty Europeans may tend stay apart from the majority of missions.

The success of NRF and respectively of ERRF on the other hand would also depend on how much Europeans would be willing to change their vision of security policy. If they stick to the opinion that the actions of NRF have to be organized according the principles of the European security policy, NRF project will not be successful, first of all, because the USA will not be interested in such a force and secondly if constructed according the European security logic NRF would be incapable of undertaking any tasks it has been created for.

Other important factors that will influence further evolution of both forces are the development of European identity and transatlantic relations. If the transatlantic link weakens significance of NATO would decrease and NRF would loose any sense. This scenario would negatively influence also the development of ERRF, which are to rely on NATO capabilities. If NATO is more to undertake the function of political forum, it is likely, that the USA would be willing to organize its military activities outside NATO, most likely through ad hoc coalitions. However this choice may pose the USA with serious problems regarding unilateral behavior that have become obvious in Iraq. On the other hand, if NRF project does not succeed, NATO significance may decrease therefore endangering transatlantic link. Thus perspectives of NRF and NATO as an Alliance are very mutually interrelated. The success of ERRF in this context is probably least important. Even if this project will not be successful in the short run, missions envisaged for ERRF might be transferred to NATO. Nevertheless, having in mind that NRF and ERRF are to use the same capabilities it is still important that Europeans would ensure enough of necessary capabilities for both forces, even if ERRF fails due to for instance institutional problems.

In the meanwhile there is support for both projects and it is likely that the NRF will be fully implemented by 2006 . Europeans are interested to keep the USA in NATO and the effective NRF is essential for that purpose. For the Americans NRF is indispensable, as providing with the opportunities to legitimize the American security concept and respective international behavior. Moreover NRF could more actively involve the allies into the regions, which extend the limits of European traditional interests and ease military costs of the USA.

ERRF project, on the other hand, is acceptable for the Americans and proAmerican Europeans only if it is strictly limited to the enhancement of Europeans military capabilities in general and to the missions of very low intensity. Though some countries, especially France are willing to devote ERRF the more ambitious role, it seems that at least in the short perspective (at least until the EU does not change its identity from a regional into the more global one) ERRF will remain more of the declarative character and will participate in low intensity missions, similar to 
those already carried out in Macedonia and the Democratic Republic of Congo, or in those of more civilian character.

On one hand defense spending is likely to remain one of the main indicators of European countries' concernment with ERRF. On the other hand, situation may change if the EU would succeed in coping with internal problems, enlargement and integration that would strengthen the EU identity. The ERRF will not be capable of carrying out significant military operations until the EU would not be able to consolidate diverging interests of member states. The position of the USA administration and public opinion both in the USA and Europe may also play significant role in the development of both forces. It is also worth taking into account which organization will propose better structures for cooperation with other countries such as Russia, China etc.

\section{The prospects of the Lithuanian involvement in NRF and ERRF}

In May 2004 Lithuania became full right member of the EU and NATO, and respectively has to participate in the development of ERRF and the NRRF and, possibly, in their operations. Although NRF is relatively new Lithuania already contemplates its possible contribution to NRF. Initially Lithuania considered of contributing with one squadron of special forces that is already participating in the operation "Enduring Freedom" in Afghanistan. Meanwhile it is however more likely that Lithuania would limit its contribution to a water purification unit (15 people).

Although Lithuania as well as other countries of the Central and Eastern Europe (CEE) recognizes the primacy of NATO in guaranteeing security in the region it is also ready to participate in the mission carried out by ERRF. Initially it was planned to commit one mechanized motorized company platoon and infantry unit, military medics section, engineering platoon, one plane AN-26, two M-8 helicopters, two MCMs and two military ranges for ERRF purposes. Current Lithuanian capabilities indicated for ERRF include ${ }^{53}$ : special operation forces (50 people), explosive ordnance disposal team (20 people), battalion task group (1000 people), movement control team (12 people), water purification unit (15 people), railhead formation (14 people), petroleum oil lubricants unit (16 people), mine counter measures ( 38 people) ${ }^{54}$ Lithuania is also considering its possible contribution to EU battle groups.

Although Lithuania and other new members of both the EU and NATO quite actively participate in both initiatives it is worth recognizing that small states cannot contribute much to rapid reaction forces. First of all those states lack expensive modern capabilities. Secondly, the structure of their armed forces usually differs from the structure necessary for rapid reaction forces. This is especially relevant for the CEE countries where armed forces had been created initially relying on the principle of territorial defense and which are moreover experiencing economic hardships. Trying to solve at least some of those problems small countries may benefit

\footnotetext{
${ }^{53}$ Some of those capabilities are also indicated in the proposals for NRF.

${ }^{54}$ Public Information Division, Ministry of National Defense.
} 
from joint procurement projects, however problems related to diverging interest are likely to arise later when considering where the EU has get to involved this awarness of this pact prevents small countries from taking more active steps in the domain. Moreover lack of co-operation between the EU and NATO might threaten to confuse foreign policy and defense policy lines of those states placing them between the rock and the hard place. Lithuania has assigned same military capabilities for the EU and NATO, however coordination problems between two are not totally resolved unresolved and makes defense planning more complicated.

Although Lithuania cannot contribute to NRF much it is likely that entering NATO Lithuanian and other CEE countries will positively influence internal dynamics and overall functioning of NATO. Their confidence in the Alliance and support for transatlantic partnership means that those countries will also be active advocates of line transatlantic. Thus even not devoting much capabilities to NRF CEE countries may significantly improve a political environment necessary for NRF development and operations. Moreover the fact that in Prague summit among other countries invited to contribute particular capabilities for NRF were two CEE states (Czech Republic and Romania $)^{55}$ demonstrates that even scarce special capabilities might be useful for NRF. British Cmdr Chris Perry has once noted that small states can also find their place in NRF. According to Cmdr Perry there is never too much of medical capabilities. He nevertheless draw rhe attention to mentioned the enormous gap that continues to exist between European and the USA military capabilities and emphasized that in the meanwhile the main objective is to ensure that this gap does not grow bigger. ${ }^{56}$ The CEE countries have to take this into account and reform their armed forces accordingly. They can also try to ensure necessary units of military police, explosives specialists, drivers or other specialists of logistics.

Although CEE countries also support the development of ERRF, they emphasize that ERRF should not compete with NATO and moreover, being still preoccupied with traditional threats, they stress the primacy of NATO. Russia is still perceived as a potential threat that might emerge in various forms also in a longer term. Long lasting Russian contradictions against CEE states' membership in NATO is usually understood as a testimony of Russian expansionist ambitions. Russian investment in the strategic sectors and sometimes very blur dividing lines between economy and politics, also political flirt of the Russian leaders with the leaders of other big powers, force them to be very suspicious and seek for more clear and hard security guarantees. New agreements between Russia and NATO make those countries cautious of whether NATO is to behave in the same way it was supposed to initially? Whether the 5th Article is invoked in the case of Russian aggression? Although NATO officials tend to underline that collective defense remains the core mission of the Alliance, traditional strategic thinking and preoccupation with the sovereignty may slow down reforms of armed forces in those countries aimed to pass towards special forces. It is also worth noting that the CEE region is the mix of the old and also

\footnotetext{
${ }_{55}^{5}$ Powell S. M., Rosenberg E., "NATO plans multinational rapid deployment force: 20,000 troops ready to hit trouble spots within days", http://sfgate.com/cgi-bin/article.cgi?f=/s/a/2002/11/17/ MN111299.DTL.

${ }^{56}$ See: note 12.
} 
the new threats. The concentration of military capabilities and other problems of the Cold War are as relevant to those countries as illegal migration, drug trafficking and dangers of black market. This region also faces the unique threats that are characteristic for it, that are frozen conflicts (Moldova, Southern Caucasus), unique geopolitical situations (Kaliningrad), old type regimes (Belarus, Russian organized crime etc. Therefore "soft" security and "hard" security instruments both are relevant for the CEE countries.

Although NATO still remains the most important organization in the security agendas of the CEE states, if serious contradictions would emerge between Europeans and Americans, or if NATO and/or the EU significantly transforms, double identity might become yet another problem for the region and confuse priorities of foreign and security policies in those countries. On the one hand, those states might relate their security identity with ad hoc coalitions lead by the USA. On the other hand, European identity might grow stronger. Nevertheless in the meanwhile it is most likely that CEE countries Lithuania among them will attach priority to NATO with the underlining domain of defense planning being special capabilities, which are possible to use in the missions of NRF, ERRF or even in those carried out by ad hoc coalitions.

\section{Conclusions}

Analysis of newly established institutions that have not started functioning yet (or are functioning just partly) is a very complicated process, which requires to take into account a variety of variables that sometimes are not directly related to the analyzed object. Aiming to anticipate prospects of NRF and ERRF, to define their roles and interlinks in the new security architecture and understand what consequences the introduction of both forces will have on the international security thorough analysis of both projects was conducted. The analysis has revealed several important questions regarding the use, effectiveness, interoperability of those forces and the effects they are likely to have on the overall security environment. However due to the variety of still ongoing processes in the domain it is almost impossible to find answers to the majority of those questions in the meanwhile. And still, there are some observable trends that can already put some light on the direction of NRF and ERRF evolution and help to single out the most important factors, which will inevitably effect further development of both.

Development of ERRF will certainly depend on whether European states are able to devote sufficient military capabilities to fulfill the tasks of ERRF, moreover it also matters if those capabilities are used effectively and financed properly. The article argues that the lack of military capabilities is possible to heal over the time if significant efforts are made and based with clear and strong political will. It is much more complicated however to solve problems that emerge as a consequences of contradicting national interests of member states. Due to the diverging national interests and unequal international activities, it is very difficult even to make a list of the most important EU interests that are to be defended in common. Misunderstandings of this character determine that the EU states do not have a common view on where, 
when and why ERRF is to be deployed. Moreover they cannot also agree on what capabilities they need. The Europeans are even failing to define clearly the status of ERRF. Incompatibility problems are further stimulated due to the unfavorable institutional structure of the EU second pillar, which does not provide strong institutional framework for the consensus and cannot enforce countries to keep up with their commitments. Those are likely to be the main factors determining the development of ERRF in the short term, which moreover may be slowed down due to the integration and enlargement processed in coming years.

Until the EU solves internal problems and ensures stability in the region (or at least in the immediate neighborhood) it is unlikely that the EU countries will be able to ensure sufficient support and unity for ERRF. On the other hand, if the real threat for the vital interests of member states emerges, situation might change. Nevertheless, in the short run it is likely that if ERRF will get involved in any military operations they are likely to be of a very limiter scale similar to those already carried out in FYROM and the Democratic Republic of Congo. In the longer run successful integration and enlargement may lay the foundations for more global ambitions of the EU. And still even if the EU starts acting globally it is still unclear whether it decides to rely on its military or the civilian identity. Finally it is worth mentioning that if ERRF does not succeed it might have some negative consequences on the EU evolution in general. Still it's impact on the overall security situation is likely to be very limited, because tasks envisaged for ERRF might be also implemented in NATO.

NRF and ERRF will use the same capabilities and therefore it is very important that Europeans would be constantly increasing and improving their share. Otherwise NATO might get marginalized and the USA may decide to "get out" from Europe, which in its turn would have negative impact on international security. The prospects of NRF might also get worsened because NRF is being created relying on the American security concept. It is thus unclear whether Europeans are willing to provide their capabilities to implement this concept worldwide? Cooperation between the USA and Europe might be weakened if the USA decides to perceive NRF as a pool of capabilities for the construction of ad hoc coalitions aimed to defend American interests. Competing security concepts can cause long lasting disputes between the two sides regarding the use and the mission of NRF. Moreover the perspectives of NRF evolution might have a more significant impact on international security that those of ERRF. The success or the failure of NRF might have an ultimate effect on raison d'etrè of NATO consequently affecting transatlantic link. Position of the USA administration and public opinion in both the USA and Europe is also worth to be taken into account. A lot will depend also on what organization will be able to offer better structures for the cooperation with the third countries (Russia, China, etc.).

The prospects of the common ERRF and NRF actions are still vague. Although there is a common agreement towards the NATO's right of "first response", and Europeans are left just with very limited tasks, the real division of labor is slightly likely due to the problems of political influence, interoperability, scarcity of capabilities and, finally, competing security concepts which design ERRF and NRF. 